ties had less than 4,000 students, and about 60 percent had less than 3,000 students. By the year 2000, 612 colleges and universities were consolidated into 250. Economies of scale will not automatically ensure quality, especially if the institutions that are being combined are themselves overstaffed with redundant personnel. The national framework of reform and opening up has also challenged the universities to ensure equal access and equity. China's domestic market reforms have accentuated regional disparities. After decades of struggling to develop its own model of socialist higher education with Chinese characteristics, their system has taken on some of the basic characteristics of higher education in Western societies. For example, expansion of higher education may benefit urban residents more than their poorer rural counterparts, since without sufficient dormitory rooms, universities must admit more commuters. Students from urban Beijing, for example, can become admitted to universities in China with lower scores than can rural students, despite the fact that rural students attend schools far less well equipped in terms of learning resources and qualified teachers. Yet, poor rural families have not been forgotten. Student loan schemes have been increased. Nevertheless, under current conditions, rural students from other provinces need to score higher on the national university entrance examinations than Beijing students in order to get admitted to the top universities in Beijing. In short, urban students increasingly hold the edge in access to their rural counterparts.

\section{The Global Dimension}

There are many forms of globally linked academic activity, and some universities excel more than others. Among some of the indications are the number of foreign students and scholars who flow back and forth between university systems, the global character of the curriculum, and crossnational scholarly publishing in other languages.

\section{Economic globalization, market forces, urban unemployment, administrative decentralization, and the information age are making China's colleges and universities re-examine their mission.}

China's universities are increasingly affected by global economic integration, domestic market reforms, and expanding cross-national academic exchanges. There is growing interest in joint-degree programs. The joint law degree offered by Temple University and the China Politics and Law University is one example. More global academic exchange may occur if a proposal to establish a special educational zone is supported. The motivation for

\section{Enrollment in higher education is ap- proaching 10 percent.}

creating such a zone, which is based on the success of China's four special economic and two special administrative zones, would be to stem the outflow of talent by permitting foreign universities to set up operations in China. This is especially important in the lead-up to China's participation in the WTO. Joint projects with reputable foreign universities could also create competition that would increase the quality of teaching and scholarship.

\section{Can Science Save Africa?}

\section{Mohamed H. A. Hassan}

Mohamed H. A. Hassan is president of the African Academy of Sciences and executive director of the Third World Academy of Sciences, Trieste, Italy. Address: Strada Costiera 11, 34014 Trieste, Italy. E-mail: <info@twas-online.org>.

In the late 1960s and early 1970s, science departments in many African universities, including the University of Lagos in Nigeria, Dar-es-Salaam in Tanzania, Accra in Ghana, and Khartoum in Sudan, were among the finest in the developing world. Once heralded as beacons of progress on the continent, these departments now suffer from a host of problems that have made it all but impossible for them to meet even minimal responsibilities. The difficulties encountered by Africa's science departments have impacts that extend well beyond the departments themselves. Many of the continent's most serious problems-including malnutrition, disease, and environmental degradation — cannot be met without the presence of a critical mass of African scientists working on issues of direct concern to the continent itself. Science alone cannot save Africa, but Africa without science cannot be saved. So what can be done to revive African science, and who should lead such an effort?

Major responsibility for the future of African science rests in the hands of Africa's governments. During the late 1960s and early 1970s, funding for science and technology in Africa was driven by government commitments to quality education and research. But years of political instability and chronic socioeconomic problems have turned increasingly neglected universities into destitute institutions. Whatever responsibility Africa's political institutions 
bear for the current crisis in education and research, they cannot be expected to overcome the situation on their own. Lack of financial resources and skilled personnel will make such a scenario virtually impossible. That means Africa's governments will need help from national and international aid organizations.

Yet, when it comes to science and technology, Africa does have its own internal pockets of strength. For example, such national and regional centers of scientific excellence as the Immunology Biotechnology Laboratories in Cameroon, the African Centre for Meteorological Applications in Niger, and the African Centre for Technology in Senegal could be transformed into international centers of excellence capable of functioning even more effectively than they do now. Africa has also achieved success in the application of science and technology for development that too often has been drowned out by the din of dismal news concerning Africa. The development of genetic molecular markers to improve tea harvests in Kenya, ongoing efforts to examine alternative treatments for river blindness in Uganda, sickle-cell research in Ghana, and

\section{Yet, when it comes to science and tech- nology, Africa does have its own inter- nal pockets of strength.}

studies of the use of indigenous plants for the treatment of diabetes in Madagascar are examples of science-based initiatives in Africa that deserve greater public recognition. Africa's science academies must become more active in policy debates related to science-based development. Currently, Africa, a continent with 54 nations, has only nine merit-based science academies. The need to strengthen existing academies must be accompanied by strategies to launch such institutions where they do not exist. Several African nations (among them Nigeria, South Africa, and Tanzania) have recently invested in science and technology programs and displayed a commitment to democratic principles that bodes well for the future, regardless of how fragile their current promising situations may be. The key question is whether these nations will serve as models for others to follow or become part of a litany of examples of hope unsustained.

Southern hemisphere cooperation could prove to be a key element in the enhancement of science and technology. Advanced developing nations such as Brazil, China, and India should forge strategic alliances with African nations. Not only would such alliances among developing nations make them less beholden to the "benevolence" of the North, but the kinship of experience would also represent a more realistic and effective way of addressing sci- ence-based development issues in Africa.

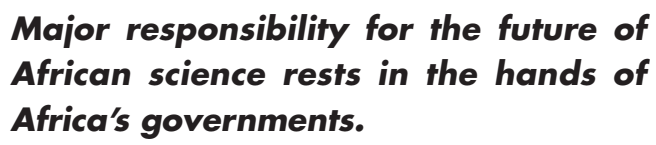

Beyond the issue of South-South cooperation is the issue of North-South cooperation. Experts estimate that 30,000 Ph.D. holders of African descent, many with science degrees, live and work outside their home countries. That figure far exceeds the total number of African-born scientists with Ph.D.s working in Africa. That is why it is important for all scientists, and especially those of African origin living and working in the North, to assist efforts to rebuild the capacities of Africa's scientific communities. And that is why it is essential for the governments of Africa to nurture environments that not only provide sufficient financial resources but also allow scientists from Africa and elsewhere to interact freely and without constraints.

(This article is reprinted from the Third World Academy of Sciences Website. See <http://www/twas-online.prg>.)

\section{Conspiracy of Silence: AIDS on African University Campuses: A Report}

In Challenging the Challenger: Understanding and Expanding the Response of Universities in Africa to HIV/AIDS, M. J. Kelly, a professor at the University of Zambia, eloquently documents the failure of many African universities to speak out and confront the HIV/AIDS crisis head-on. This report is based on case studies of seven universities in Benin, Ghana, Kenya, Namibia, South Africa, and Zambia, commissioned by the World Bank-led ADEA Working Group on Higher Education. It seeks to understand how the disease is affecting African universities and to identify responses and coping mechanisms that might profitably be shared with sister institutions in similar circumstances.

\section{A Disquieting Picture}

The report's overriding message is that the institutions studied remain in the dark concerning the HIV/AIDS situation on their own campuses. The first part of the report puts this matter into the broader context of African development and examines some of the social and economic consequences of the epidemic. In 1999, over two million 